[Case Report]

\title{
A Case of Resistance to Thyroid Hormone (RTH) with a Negative Family History with Diagnosis Based on Persistent Palpitations
}

\author{
Akira Kurozumi ${ }^{1}$, Yosuke OKadA ${ }^{1}$, Tadashi Arao ${ }^{1,2}$ and Yoshiya TANaKA ${ }^{1 *}$ \\ ${ }^{1}$ First Department of Internal Medicine, School of Medicine, University of Occupational and Environmental Health, \\ Japan. Yahatanishi-ku, Kitakyushu 807-8555, Japan \\ ${ }^{2}$ Department of Internal Medicine, Japan Labor Health and Safety Organization Kyushu Rosai Hospital, Moji Medi- \\ cal Center.
}

\begin{abstract}
Approximately 140 different mutations of thyroid hormone receptor $\beta$ (TR $\beta$ ) have been identified in resistance to thyroid hormone $(\mathrm{RTH})$. We report herein a middle-aged man with a negative family history who was diagnosed with RTH based on persistent palpitations. Genetic analysis showed a TR $\beta$ mutation causing the substitution of alanine for proline 453 (P453A) in exon 10. Since treatment of RTH is different from that of Graves' disease and thyroid stimulating hormone-producing adenoma (TSHoma), a genetic analysis should be performed even in patients who have a negative family history of RTH and who are free of TSHoma when they present with persistent inappropriate secretion of thyroid stimulating hormone (SITSH).
\end{abstract}

Keywords : resistance to thyroid hormone, thyroid hormone receptor $\beta$, syndrome of inappropriate secretion of thyroid stimulating hormone.

(Received September 2, 2016, accepted October 11, 2016)

\section{Introduction}

Resistance to thyroid hormone (RTH) has been reported in more than 500 families since the first thyroid hormone receptor beta (TR $\beta)$ gene mutation was identified in 1989 [1]. The disease has an autosomal dominant mode of inheritance, and approximately 140 different mutations of the TR $\beta$ gene have been identified. It is estimated that there are more than 40,000 RTH patients worldwide [2]. No TR $\beta$ mutations are observed in approximately $15 \%$ of RTH cases [1], and the resistance in these cases is caused by mutations in the monocarboxylate transporter 8 (MCT8) [3] and the thyroid hormone receptor alpha (TR $\alpha)$ genes [4]. There are an estimated 3,000 cases in Japan of RTH associated with $\operatorname{TR} \beta$ gene mutations. Here we report a case of RTH without a family history, diagnosed by persistent palpitations.

\section{Case report}

The patient was a 44-year-old man who had been prone to episodes of nervousness since early childhood. Although a physical examination showed no obvious abnormalities, the patient reported experiencing periods of palpitations since April 2009 that were not induced by any known stimuli (no other signs of thyrotoxicosis) and presented to the Cardiology Department at our hospital because of exacerbation of palpitations. Electrocardiography showed sinus tachycardia, with

*Corresponding Author: Yoshiya TANAKA, MD, PhD, First Department of Internal Medicine, School of Medicine, University of Occupational and Environmental Health, Japan. 1-1 Iseigaoka, Yahatanishi-ku, Kitakyushu 807-8555, Japan, Phone: +81-93-603-1611, Fax: +81-93-691-9334, Email: tanaka@med.uoeh-u.ac.jp 
a rate of $160 / \mathrm{min}$ at the time of presentation, which disappeared following intravenous administration of $\beta$-blocker. The results of blood tests indicated inappropriate secretion of thyroid stimulating hormone (SITSH): thyroid stimulating hormone (TSH) 1.94 $\mu \mathrm{IU} / \mathrm{m} l$, free triiodothyronine (FT3) $4.47 \mathrm{pg} / \mathrm{ml}$ and free thyroxine (FT4) $2.18 \mathrm{ng} / \mathrm{d} l$. Based on these findings, the patient was referred to our department in July 2009. Follow-up examinations showed persistence of SITSH (TSH $2.54 \mu \mathrm{IU} / \mathrm{ml}$, FT4 $3.00 \mathrm{ng} / \mathrm{d} l$ ). Accordingly, the patient was admitted to our department in August 2009 for further examination and treatment.

On admission, a thyroid autoantibody test showed negative results (Table 1), and a physical examination showed no thyroid enlargement and no evidence of increased blood flow on ultrasonography. Pituitary magnetic resonance imaging (MRI) showed no evidence of tumor, and a thyrotropin-releasing hormone (TRH) stimulation test showed a normal TSH response (Table 2). No increases in sex-hormone binding glob- ulin (SHBG) or TSH- $\alpha$ subunit were noted, thus the presence of a TSH-producing adenoma (TSHoma) was ruled out (although a T3 inhibition test was not performed). The family history was negative for RTH. The patient was followed up while on treatment with $\beta$-blockers at the onset of palpitations. The patient visited our department again in October 2013 because of persistent palpitations. Due to the persistent SITSH (TSH $2.43 \mu \mathrm{IU} / \mathrm{m} l$, FT3 $4.90 \mathrm{pg} / \mathrm{m} l$, FT4 $2.25 \mathrm{ng} / \mathrm{d} l$ ), we obtained informed consent and performed a genetic analysis for TR $\beta$ mutations for a definitive diagnosis.

Table 2. Results of TRH stimulating test

\begin{tabular}{lcll}
\hline parameter & fasting & $30 \mathrm{~min}$ & $60 \mathrm{~min}$ \\
\hline $\mathrm{TSH}(\mu \mathrm{IU} / \mathrm{m} l)$ & 5.64 & 32.15 & 21.79 \\
$\mathrm{PRL}(\mathrm{ng} / \mathrm{m} l)$ & 12.2 & 45.6 & 25.9 \\
\hline
\end{tabular}

TRH: thyrotropin releasing hormone, TSH: thyroid stimulating hormone, PRL: prolactin

Table 1. Laboratory data on admission

\begin{tabular}{|c|c|c|c|c|c|}
\hline CBC & & Biochemistry & & Thyroid-related & \\
\hline Leukocytes $\left(/ \mathrm{mm}^{3}\right)$ & 5100 & $\mathrm{TP}(\mathrm{g} / \mathrm{d} l)$ & 6.8 & $\mathrm{TSH}(\mu \mathrm{IU} / \mathrm{m} l)$ & 1.63 \\
\hline Neutrophils (\%) & 62.3 & $\mathrm{Alb}(\mathrm{g} / \mathrm{d} l)$ & 4.3 & FT3 $(\mathrm{pg} / \mathrm{m} l)$ & 3.50 \\
\hline Eosinophils (\%) & 1.0 & AST (IU/l) & 15 & $\mathrm{FT} 4(\mathrm{ng} / \mathrm{d} l)$ & 2.52 \\
\hline Basophils (\%) & 0.4 & ALT (IU/l) & 16 & T3 (ng/ml) & 2.02 \\
\hline Lymphocytes (\%) & 31.2 & $\gamma$-GTP $(\mathrm{IU} / l)$ & 11 & $\mathrm{~T} 4(\mu \mathrm{g} / \mathrm{d} l)$ & 15.9 \\
\hline Monocytes (\%) & 5.1 & LDL-C $(\mathrm{mg} / \mathrm{d} l)$ & 158 & $\operatorname{TRAb}(\mathrm{U} / \mathrm{m} l)(<2.0)^{\natural}$ & $<0.3$ \\
\hline Erythrocytes $\left(\times 10^{4} / \mathrm{mm}^{3}\right)$ & 492 & $\mathrm{TG}(\mathrm{mg} / \mathrm{d} l)$ & 122 & TG-Ab $(\mathrm{U} / \mathrm{m} l)(<28.0)^{\natural}$ & 25 \\
\hline Hemoglobin $(\mathrm{g} / \mathrm{d} l)$ & 14.5 & HDL-C $(\mathrm{mg} / \mathrm{d} l)$ & 49 & $\mathrm{TPO}-\mathrm{Ab}(\mathrm{U} / \mathrm{m} l)(<16.0)^{\natural}$ & 8 \\
\hline Hematocrit (\%) & 43.5 & BUN $(\mathrm{mg} / \mathrm{d} l)$ & 11 & SHBG $(\mathrm{nmol} / l)$ & 38.2 \\
\hline Platelets count $\left(\times 10^{4} / \mathrm{mm}^{3}\right)$ & 24.4 & $\mathrm{Cr}(\mathrm{mg} / \mathrm{d} l)$ & 0.82 & TSH- $\alpha$ subunit $(\mathrm{ng} / \mathrm{m} l)$ & 0.2 \\
\hline Urine & & $\mathrm{eGFR}(\mathrm{ml} / \mathrm{min})$ & 81.4 & Endocrine-related & \\
\hline $\mathrm{pH}$ & 7.5 & $\mathrm{Na}(\mathrm{mEq} / \mathrm{m} l)$ & 134 & $\mathrm{ACTH}(\mathrm{pg} / \mathrm{m} l)$ & 29.5 \\
\hline glucose & $(-)$ & $\mathrm{K}(\mathrm{mEq} / \mathrm{m} l)$ & 4.1 & $\operatorname{cortisol}(\mu \mathrm{g} / \mathrm{d} l)$ & 10.8 \\
\hline protein & $(-)$ & $\mathrm{Cl}(\mathrm{mEq} / \mathrm{m} l)$ & 107 & $\mathrm{LH}(\mathrm{mIU} / \mathrm{m} l)$ & 2.5 \\
\hline ketone & $(-)$ & & & $\mathrm{FSH}(\mathrm{mIU} / \mathrm{m} l)$ & 4.4 \\
\hline occult blood & $(-)$ & & & PRL $(\mathrm{ng} / \mathrm{m} l)$ & 9.6 \\
\hline
\end{tabular}

CBC: complete blood count, ${ }^{\natural}$ : normal range, TP: total protein, Alb: albumin, AST: aminotransferase, ALT: alanine aminotransferase, $\gamma$-GTP: $\gamma$-glutamyl transpeptidase, LDL-C: low density lipoprotein cholesterol, TG: triglyceride, HDL-C: high density lipoprotein cholesterol, BUN: blood urea nitrogen, Cr: creatinine, eGFR: estimated glomerular filtration rate, Na: sodium, K: potassium, Cl: chloride, TSH: thyroid stimulating hormone, FT3: free triiodothyronine, FT4: free thyroxine, T3: triiodothyronine, T4: thyroxine, TRAb: TSH receptor antibody, TG-Ab: thyroglobulin antibody, TPO-Ab: thyroid peroxidase antibody, SHBG: sex hormone binding protein, ACTH: adrenocorticotrophic hormone, LH: luteinizing hormone, FSH: follicle stimulating hormone, PRL: prolactin 


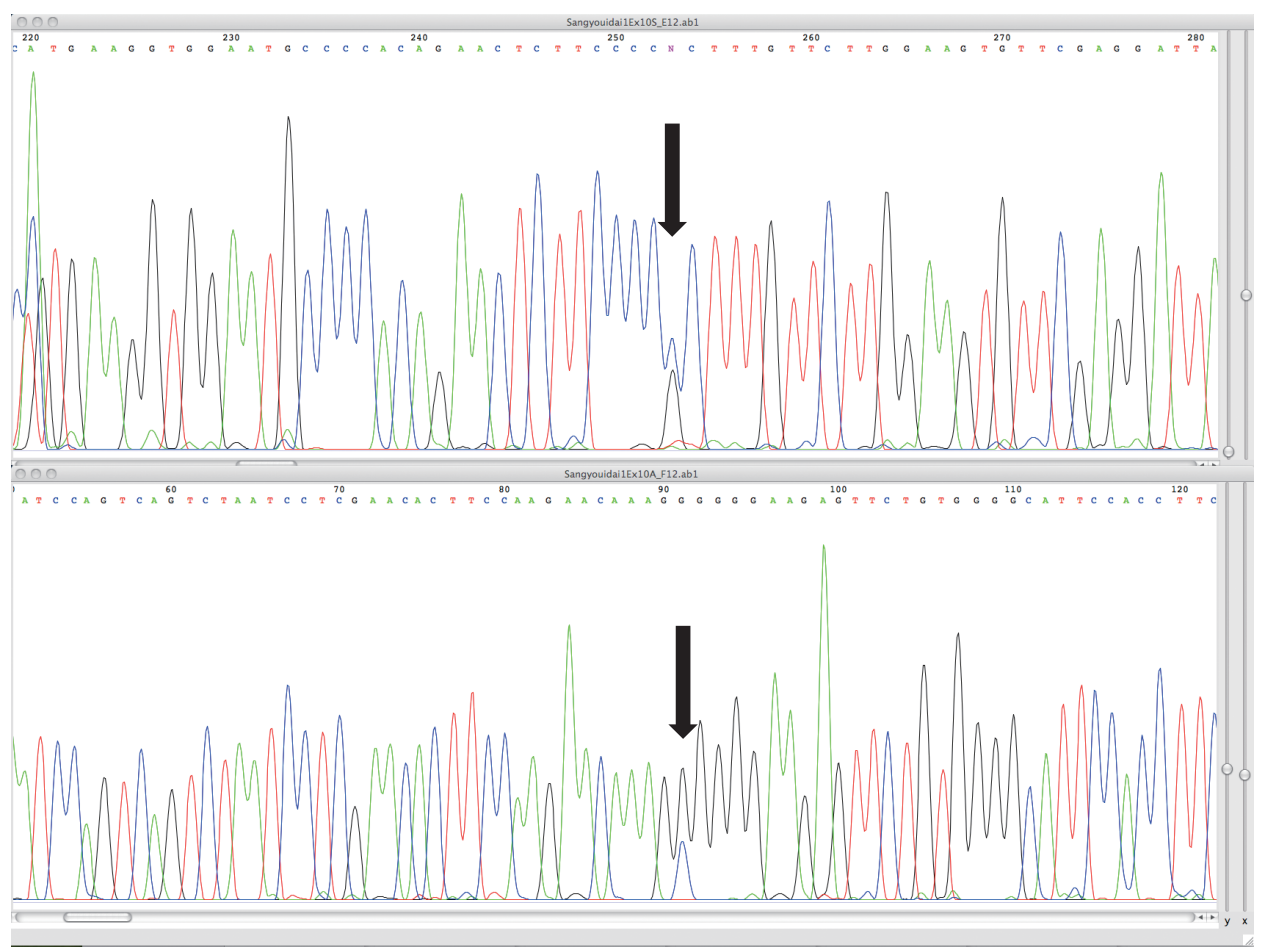

Fig. 1. Genetic analysis of thyroid hormone receptor beta (TR $\beta)$ identified a mutation causing substitution of alanine for proline (P453A) in exon 10. - : adenine, - : thymine, - : cytosine, $\longrightarrow$ : guanine, $\longrightarrow$ : mutation points.

The result showed that proline had mutated to alanine (P453A) in exon 10 (Fig. 1). The above findings confirmed the diagnosis of RTH. Since the patient's parents and other members of the extended family had already died (causes of death unknown), we performed genetic screening on the patient only. The patient is currently being followed-up with symptomatic treatment of palpitation episodes with $\beta$-blockers.

\section{Discussion}

We reported a patient of RTH with a negative family history who was diagnosed, based on persistent palpitations, to have a TR $\beta$ mutation causing the substitution of alanine for proline 453 (P453A). To date, the P453A mutation has been reported in only one family in Japan [5] and 8 families worldwide [6-10]. The P453A mutation results in decreased affinity of TR $\beta$ for T3, and the mutant protein has only $17 \% \mathrm{~T} 3$ affinity compared to the wild-type $[8,9]$. Several cases have been reported, with substitution of proline with alanine, serine or threonine at position 453 . Goiter is a common manifestation of RTH and is observed in $66-95 \%$ of patients [11]. Approximately $70 \%$ of RTH patients with a P453A mutation also develop goiter, although that was absent in our case (Table 3). Although goiter is not a clinical concern in general, when it is of clinical significance, administration of a large single dose of synthetic T3 preparation at one-day intervals is reported to result in almost complete inhibition of TSH secretion and reduction of goiter [12].

T3 acts through TR $\alpha$ in the cardiac muscle, and many patients with RTH complain of palpitations. The patient reported here also complained mainly of palpitations, as has been reported in other RTH cases with the P453A mutation. However, as reported by Weiss et al [13], the clinical disease type is not related to the gene mutation.

RTH can be clinically classified as generalized RTH (GRTH) or pituitary RTH (PRTH). RTH with a normal physical condition or a hypothyroid condition is classified as GRTH, while RTH with thyrotoxicosis is classified as PRTH. The patient reported herein had tachycardia as thyrotoxicosis, so could be classified as PRTH. 
Although FT4 values vary among RTH cases, these values are reportedly associated with impairment of T3 binding activity [13], except in cases of reduced hormone affinity and dominant negative. The impairment of T3 binding activity affinity in patients with a P453A mutation is $17 \%$ of that observed in the wild type.

RTH is a condition in which the reduced tissue responsiveness to thyroid hormone is compensated for by elevated TSH and FT4 levels [1]. Therefore, administration of anti-thyroid drugs or surgical treatment may result in thyroid malfunction, necessitating continuous treatment thereafter. Various mistreatments of RTH cases with P453A mutation have been reported (Table 3) $[6,7,10]$, and a recent study that reported painless thyroiditis complicating P453A mutations highlights the need for careful judgment in making an appropriate treatment decision [5]. It is important to monitor clinical symptoms carefully and to maintain the values of FT4 and FT3 below the upper limits and to keep the TSH level within the normal range.

Treatment of RTH is different from that of Graves' disease and TSHoma, therefore even if the patient has a negative family history of RTH, genetic analysis should be performed when SITSH persists and TSHoma can be ruled out.

\section{Acknowledgments}

The authors thank Dr. Y. Hayashi and Y. Murata from Nagoya University for gene analysis of TR $\beta$.

\section{Conflicts of Interest}

The authors declare no conflict of interest.

\section{References}

1. Refetoff S (2008): Resistance to thyroid hormone: one of several defects causing reduced sensitivity to thyroid hormone. Nat Clin Pract Endocrinol Metab 4: 1

2. Lee S, Young BM, Wan W, Chan IH \& Privalsky ML (2011): A mechanism for pituitary-resistance to thyroid hormone (PRTH) syndrome: a loss in cooperative coactivator contacts by thyroid hormone receptor (TR) beta2. Mol Endocrinol 25: 1111-1125

3. Dumitrescu AM, Liao XH, Best TB, Brockmann K \& Refetoff S (2004): A novel syndrome combining thyroid and neurological abnormalities is associated with mutations in a monocarboxylate transporter gene. Am J Hum Genet 74: 168-175

4. Bochukova E, Schoenmakers N, Agostini M et al (2012): A mutation in the thyroid hormone receptor alpha gene. N Engl J Med 366: 243-249

5. Taniyama M, Otsuka F, Tozaki T \& Ban Y (2013): Thyroid profiles in a patient with resistance to thyroid hormone and episodes of thyrotoxicosis, including repeated painless thyroiditis. Thyroid 23: 898-901

6. Florkowski CM, Brownlie BE, Croxson MS, Manning P, Farrand S, Smith G, Potter HC \& George PM (2006): Thyroid hormone resistance: the role of mutational analysis. Intern Med J 36: 738-741

Table 3. Clinical features of reported RTH patients with P453A mutation

\begin{tabular}{|c|c|c|c|c|c|c|}
\hline $\begin{array}{l}\text { Age at } \\
\text { diagnosis/sex }\end{array}$ & Country & goiter & palpitation & $\begin{array}{l}\text { Other family } \\
\text { members with RTH }\end{array}$ & Mistreatment & Reference \\
\hline $40 / \mathrm{F}$ & New Zealand & + & + & Daughter & $\mathrm{ATD} \cdot \mathrm{RAI}$ & [6] \\
\hline $37 / F$ & Turkey & + & + & Son & $\begin{array}{l}\text { ATD } \\
\text { thyroidectomy }\end{array}$ & {$[7]$} \\
\hline $45 / \mathrm{M}$ & United Kingdom & unknown & unknown & unknown & unknown & {$[8]$} \\
\hline $46 / F$ & France & - & + & " & " & [9] \\
\hline $18 / F$ & Turkey & + & - & Mother & - & {$[10]$} \\
\hline $48 / \mathrm{F}$ & " & + & unknown & Daughter & thyroidectomy & {$[10]$} \\
\hline $44 / F$ & Japan & + & + & - & - & {$[5]$} \\
\hline $44 / \mathrm{M}$ & " & - & + & - & - & our case \\
\hline
\end{tabular}

RTH: resistance to thyroid hormone, ATD: anti thyroid drug, RAI: radioactive iodine 
7. Bayraktaroglu T, Noel J, Alagol F, Colak N, Mukaddes NM \& Refetoff S (2009): Thyroid hormone receptor beta gene mutation (P453A) in a family producing resistance to thyroid hormone. Exp Clin Endocrinol Diabetes 117: 34-37

8. Adams M, Matthews C, Collingwood TN, Tone Y, Beck-Peccoz P \& Chatterjee KK (1994): Genetic analysis of 29 kindreds with generalized and pituitary resistance to thyroid hormone. Identification of thirteen novel mutations in the thyroid hormone receptor beta gene. J Clin Invest 94: 506-515

9. Margotat A, Sarkissian G, Malezet-Desmoulins C, Peyrol N, Vlaeminck Guillem V, Wémeau JL \& Torresani J (2001): Identification of eight new mutations in the cerbAB gene of patients with resistance to thyroid hormone. Ann Endocrinol (Paris) 62: 220-225 (in French)

10. Aksoy DY, Gurlek A, Ringkananont U, Weiss RE \&
Refetoff S (2005): Resistance to thyroid hormone associated with autoimmune thyroid disease in a Turkish family. J Endocrinol Invest 28: 379-383

11. Refetoff S \& Dumitrescu AM (2007): Syndromes of reduced sensitivity to thyroid hormone: genetic defects in hormone receptors, cell transporters and deiodination. Best Pract Res Clin Endocrinol Metab 21: 277305

12. Anselmo J \& Refetoff S (2004): Regression of a large goiter in a patient with resistance to thyroid hormone by every other day treatment with triiodothyronine. Thyroid 14: 71-74

13. Weiss RE, Marcocci C, Bruno-Bossio G \& Refetoff $S$ (1993): Multiple genetic factors in the heterogeneity of thyroid hormone resistance. J Clin Endocrinol Metab 76: $257-259$ 
繰り返す動悸を契機に診断に至った家族歴を有さない甲状腺ホルモン不応症の1例

黑住 旭 ${ }^{1}$, 岡田 洋右 ${ }^{1}$, 新生 忠司 ${ }^{1,2}$, 田中 良哉 ${ }^{1}$

1 産業医科大学 医学部 第 1 内科学講座

2 九州労災病院 門司メディカルセンター 内科

要旨：甲状腺ホルモン不応症 $(\mathrm{RTH})$ は, これまで約 140 種類の甲状腺ホルモン受容体ベー夕 $(\mathrm{TR} \beta)$ 遺伝子変異 が同定されている。今回家族歴は有さないが, 繰り返す動悸を契機にRTHの診断に至った中年男性の 1 例を経験し たので報告する．TR $\beta$ 遺伝子解析の結果, 第 10 エクソン, 453 番目のプロリンからアラニンへの変異を認めた. RTH はバセドウ病やTSH (thyroid stimulating hormone) 産生腫瘍(TSHoma) とは治療法がまったく異なるため, RTHの家族 歴を有さなくても, 不適切 TSH 分泌症候群が持続しTSHomaが否定的な場合には, 積極的に遺伝子解析を行うことが 重要である.

キーワード：甲状腺ホルモン不応症, 甲状腺ホルモン受容体ベー夕, 不適切TSH分泌症候群.

J UOEH(産業医大誌) 38(4)：291 - 296 (2016) 